\title{
Functionally interacting telomerase RNAs in the yeast telomerase complex
}

\author{
John Prescott and Elizabeth H. Blackbum \\ Departments of Microbiology and Immunology, and Biochemistry and Biophysics, University of California, San Francisco, \\ San Francisco, California 94143-0414 USA
}

\begin{abstract}
The ribonucleoprotein (RNP) enzyme telomerase from Saccharomyces cerevisiae adds telomeric DNA to chromosomal ends in short increments both in vivo and in vitro. Whether or not telomerase functions as a multimer has not been addressed previously. Here we show, first, that following polymerization, the telomerase RNP remains stably bound to its telomeric oligonucleotide reaction product. We then exploit this finding and a previously reported mutant telomerase RNA to demonstrate that, unexpectedly, the S. cerevisiae telomerase complex contains at least two functionally interacting RNA molecules that both act as templates for DNA polymerization. Here, functional telomerase contains at least two active sites.
\end{abstract}

[Key Words: Telomerase; yeast; dimer; nondissociative; nonprocessive]

Received May 28, 1997; revised version accepted September 12, 1997.

Maintenance of telomeres in most eukaryotes involves replenishment of telomeric DNA using telomerase, a highly specialized cellular reverse transcriptase with a short segment of its RN A subunit as a template for the polymerization of telomeric DNA ( $\mathrm{u}$ e et al. 1990; for review, see Greider 1996). In most eukaryotes, telomeric DN A consists of di rect repeats of a simple sequence that is typically G-rich on the strand extending $5^{\prime} \rightarrow 3^{\prime}$ toward the telomeric terminus (TTAGGG in vertebrates, $\mathrm{T}(\mathrm{G})_{2-3}(\mathrm{TG})_{1-6}$ in Saccharomyces cerevisiae; for review, see Henderson 1995). Although the bulk of telomeric DNA is double stranded, the extreme terminus contains a 3 ' singl e-stranded overhang during part, if not all, of the cell cycle (Klobutcher et al. 1981; Henderson and Blackburn 1989; Wellinger et al. 1993; Makarov et al. 1997). Proteins that bind sequence specifically to doublestranded tel omeric DN A (Shore 1994; Chong et al. 1995; Promisel Cooper et al. 1997) are involved in regulating telomere length, which suggests that the telomeric DN A-protein complex controls the action of telomerase at the telomeric terminus (Krauskopf and Blackburn 1996; Li and Lustig 1996; Promisel Cooper et al. 1997; van Steensel and de Lange 1997). T el omere maintenance is important because telomeres provide many functions to the cell: They "cap" and protect chromosome ends (Blackburn 1994; Zakian 1995), may mediate proper chromosome separation in mitosis, and may be involved in positioning chromosomes within the nucleus (Dernberg et al. 1995). Removal of a telomere in the yeast $S$. cerevisiae results in rapid chromosome loss (Sandell and Zakian 1993), and mutating the template sequence of telomerase RNA in Tetrahymena blocks cells in late

${ }^{1}$ Corresponding author.

E-MAIL porter@itsaucsf.edu; FAX (415) 476-8201. anaphase, preventing chromosome segregation (Kirk et al. 1997). Telomere-nuclear envel ope associations and telomere-telomere associations are well documented phenomena in both mitotic and meiotic cells, al though neither their function not the mechanisms by which they occur are well understood (Dernberg et al. 1995).

Telomerase activity has been identified from a wide variety of eukaryotes (Greider and Blackburn 1985; Zahler and Prescott 1988; Morin 1989; Shippen-Lentz and Blackburn 1989; Prowse et al. 1993; Cohn and Blackburn 1995; Fitzgeral d et al. 1996). Tel omerase from Tetrahymena contains a 159-nucleotide RNA and at least two protein subunits of 80 and $95 \mathrm{kD}$ (Greider and Blackburn 1989; Collins et al. 1995). Mammalian telomerases contain an 450-nucleotide RN A and at least one protein, an $\sim 250-k D$ protein subunit with homology to Tetrahymena p80 (Blasco et al. 1995; Feng et al. 1995; Harrington et al. 1997; Nakayama et al. 1997). A second likely protein subunit of human telomerase, which contains conserved reverse transcriptase motifs and homology to the only known protein subunit of yeast telomerase, was identified recently (M eyerson et al . 1997; N akamura et al. 1997). S. cerevisiae telomerase contains a 1.3-kb RN A (TLC 1) (Singer and Gottschling 1994) and at least one protein component, the 103-kD Est2p (Lendvay et al. 1996; Lingner et al. 1997).

Previously, we characterized a series of mutant tel omerases containing base changes in the template domain of the TLC1 RNA (Prescott and Blackburn 1997). M ost of these mutant enzymes were active and could stably maintain telomeres, albeit in a somewhat shortened form. However, one template mutation, 476GUG, destroyed telomerase activity both in vivo and in vitro (Prescott and Blackburn 1997). This mutation caused progressive tel omere shortening, sl ow growth, and even- 
tual cellular senescence, phenotypes characteristic of yeast cells unable to replenish their telomeric DNA (Lundblad and Szostak 1989; Singer and Gottschling 1994; McEachern and Blackburn 1995). However, unexpectedly, coexpressing the mutant and wild-type telomerase RNAs caused restoration of activity of the tlc1476GU G mutant telomerase RNA, both in vivo and in vitro.

Here we show that tel omerase in S. cerevisiae is active in a multimeric form containing at least two functional RNAs in a single telomerase ribonucleoprotein (RNP) complex. We demonstrate that this functioning as a multimer is required for wild-type TLC1 RNA to restore activity of 476GUG telomerase, demonstrating that the active sites interact with each other. Following even very limited polymerization in vitro, this multimeric polymerase remains stably bound to its DNA oligonucleotide reaction product. These results suggest the possibility that following telomere elongation telomerase may remain bound to the tel omere and hence might contribute to capping functions and telomere-telomere interactions.

\section{Results}

S. cerevisiae telomerase exhibits single turnover kinetics

We and others have shown that in vitro, S. cerevisiae telomerase polymerizes primarily a single, often incomplete round of TLC1 RN A-templated primer elongation under a variety of conditions (C ohn and Blackburn 1995; Lingner et al. 1997; Prescott and Blackburn 1997). This preponderance of single-round reaction products suggested three possibilities: (1) Reaction products dissociate readi ly from tel omerase and are not further el ongated because of competition by excess primer; (2) telomerase is inherently limited to one round of extensi on and must be reactivated before additional extension cycles; or (3) reaction products remain tightly associated with telomerase but fail to translocate, preventing subsequent rounds of elongation. To distinguish between these possibilities, we first analyzed the kinetics of the telomerase reaction. Using the DNA primer shown in Figure $1 A$, polymerization to the end of the template sequence in the TLC1 telomerase RNA produced reaction products extended primarily by up to 7 nucleotides, as described previously (Prescott and Blackburn 1997). Product yield increased linearly with increasing enzyme concentration, indicating that enzyme was limiting in these reactions (Fig. 1B). Varying the primer concentration indicated that the apparent $\mathrm{K}_{\mathrm{m}}$ for the reaction was well below the primer concentration used in standard assays (Fig. 1C). However, under reaction conditions in which enzyme was limiting and primer in vast excess, total product yield reached a plateau by $\sim 1-2 \mathrm{~min}$ (Fig. 1D,E). During the reaction, the product profile gradually shifted, from products initially extended mainly by 3-5 nucleotides (referred to as +3 to +5 products) to more predominant +5 to +7 products late in the reaction (Fig.


Figure 1. S. cerevisiae tel omerase exhibits single turnover kinetics. (A) Optimal alignment between the TLC1 RN A templating domain and the standard 14-nucleotide primer. $(B, C)$ Products from in vitro tel omerase reactions containing $0.1,0.3,1,3$, or $10 \mu \mathrm{l}(\sim 30-3000 \mathrm{fm}$ TLC1 RNA) (B, lanes 1-5) wild-type telomerase, and $0,0.001,0.003,0.01,0.03,0.1,0.3$, or $1.0 \mu \mathrm{m}$ primer (C, lanes 1-8. Terminal transferase labeled primer (lane M) marks the primer +1 position. (D) Products from in vitro tel omerase reactions incubated for various time periods. (E) The total of the seven major reaction products in $D$ are quantitated, in arbitrary units. (F) Products from a 2-min reaction (lane 1) followed by an additional 28-min incubation with (lane 2) or without (lane 3) excess unlabel ed dTTP.

1D, cf. first five lanes with last five lanes). In pulse/ chase experiments (chased with excess unlabeled dTTP), the +4 and +5 labeled products were chased into longer ( +6 and +7 ) products (Fig. 1F, cf. Ianes 1 and 2). Such results are not predicted if telomerase undergoes multiple rounds of dissociative primer elongation. Instead, they were consistent with either tel omerase being inherently limited to a single round of telomere extension, requiring "reactivation" before further catalysis, or with telomerase remaining functionally associated with its newly elongated primer in a manner that prevents further elongation. 


\section{S. cerevisiae telomerase fails to release its reaction product}

To test directly whether tel omerase remains stably associated with its reaction product, following a polymerization reaction the reaction mix was size-fractionated using gel filtration chromatography. Conditions were used in which the large telomerase enzyme complex elutes in the void volume, ahead of unincorporated $\alpha$ ${ }^{32} \mathrm{P}$-labeled nucleoside triphosphates (dNTPs) and free, product-length oligonucleotides. As shown in Figure 2A, a shoulder of ${ }^{32} \mathrm{P}$ label (fractions 13-16) eluted ahead of the unincorporated ${ }^{32} \mathrm{P}$ dN TPs (fractions 17 and higher), suggesting that the short (15- to 21-nucleotide) ${ }^{32} \mathrm{P}$-labeled reaction products remai ned associated with a large complex. Strikingly, no detectable telomerase reaction products el uted after these shoulder fractions, in the region where nontelomeric ${ }^{32} \mathrm{P}$-labeled oligonucl eotides of the same size as the reaction products eluted, as shown by denaturing acrylamide gel electrophoresis (Fig. 2B, fractions 19-22; data not shown). Instead, the shoulder fractions contained all of the ${ }^{32} \mathrm{P}$-labeled telomerase reaction products (Fig. 2B, fractions 12-17). These telomerase reaction products coeluted with the telomerase RNP, as shown by analyzing aliquots of the same column fractions by nondenaturing gel el ectrophoresis. The discrete band of ${ }^{32} \mathrm{P}$-labeled products present in the shoul der fractions (Fig. 2C, fractions 13-16, arrow) comigrated exactly on the native gel with the telomerase RNP, as determined by transfer to a nytran membrane and hybridization to a ${ }^{32} \mathrm{P}$-label ed TLC1 gene probe (Fig. $2 \mathrm{D}$, fractions 13-16, arrow). Furthermore, the elution profile of this discrete band across the fractions (Fig. 2C) coincided with the elution profiles of both the telomerase RNP (Fig. 2D) and the bona fide oligonucleotide telomerase reaction products (Fig. 2B). The gel filtration spanned a period of $15 \mathrm{~min}$ at $22^{\circ} \mathrm{C}$, indicating that the apparent $\mathrm{t}_{1 / 2}$ for all extension products at $22^{\circ} \mathrm{C}$ is at least $15 \mathrm{~min}$. Gel filtration spanning a period of $1-2 \mathrm{hr}$ at $22^{\circ} \mathrm{C}$ showed preferential elution of the +1 to +4 elongation products in the region of the column in which free oligonucleotide markers eluted (data not shown), demonstrating that the longer $(+5,+6$, and +7$)$ reaction products are bound more stably by telomerase than the shorter products. Finally, UV cross-linking of these shoulder fractions produced a singl ${ }^{32} \mathrm{P}$-labeled protein species of $\sim 103 \mathrm{kD}$ (Fig. 2E). This protein is discussed below. We conclude that the S. cerevisiae telomerase RN P remains stably bound to its reaction product following a single, often incomplete, round of extension.

Stable enzyme-product complex formation requires interactions besides RNA template-DNA product base-pairing

The stable binding of the telomerase RN P to its DNA product predicted that a "challenge" primer, added after the initial extension reaction, would be unable to compl ete with the bound product for the enzyme's active site and therefore would not be el ongated. This was tested by primer challenge reactions initiated with a telomeric primer, present in large excess over telomerase, dGTP, $\left[\alpha{ }^{32} P\right] d T T P$, and limiting enzyme, incubated for (typically) $7 \mathrm{~min}$, followed by addition of a telomeric challenge primer of a different length and further incubation. The sets of products from each primer were distinguishable because of their different lengths. In the experiment shown in Figure 3A, each of the primers used as the initiating primer was efficiently elongated when it was

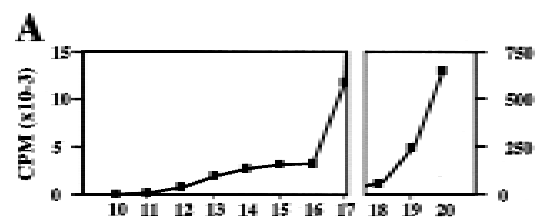

B



L. 10111213141516171819302122
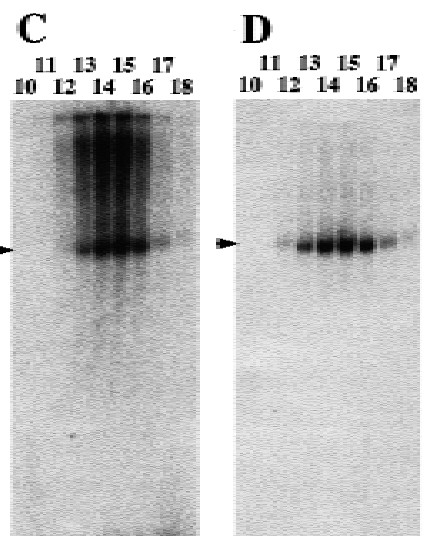

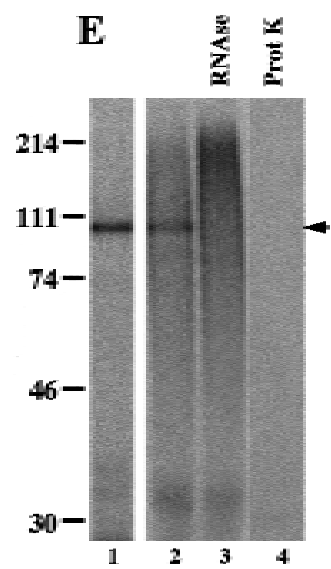

Figure 2. Telomerase remains stably bound to its primer substrate following polymerization. (A-C) Products from an in vitro tel omerase reaction were separated on Sephacryl S-300, and al iquots of each fraction were counted in a scintillation counter (A) before being either separated on a $15 \%$ acrylamide/ $8 \mathrm{M}$ urea gel (B), or a $3 \%$ acrylamide/ $0.6 \%$ agarose native gel (C) and exposed to film. (D) The gel in C was transferred to nytran, hybridized to a label ed TLC1 DN A probe, and exposed to film $\sim 30$-fold shorter than in C. Lane numbers correspond to fraction numbers. The arrows in $C$ and $D$ align with each other and mark the position of the telomerase RN P. (E) Either the first third (Iane 1) or all (lanes 2-4) of the tel omerase containing Sephacryl S-300 fractions were pooled, UV irradiated, and separated on $9 \%$ SDS-PAGE. Control reactions were incubated with RN ase A prior to (lane 3), or proteinase $\mathrm{K}$ following (lane 4), UV irradiation. The arrow marks an $103-k D$ cross-linked protein. 
A

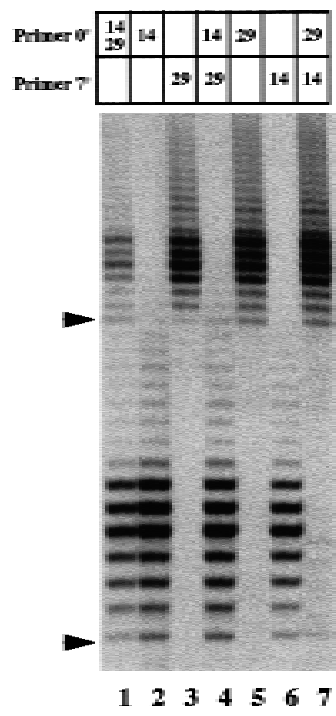

B

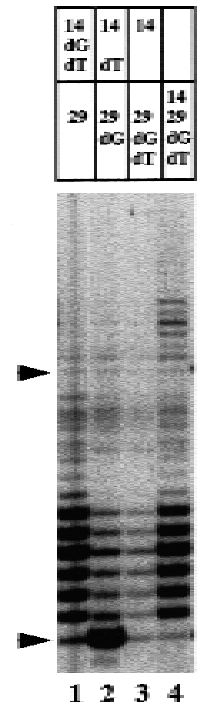

C



D

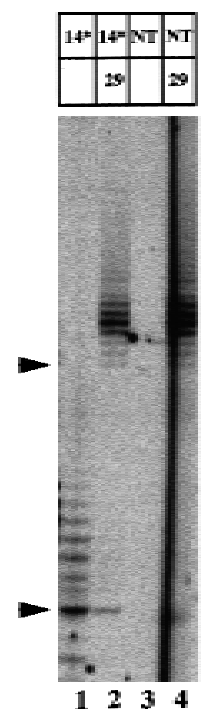

E

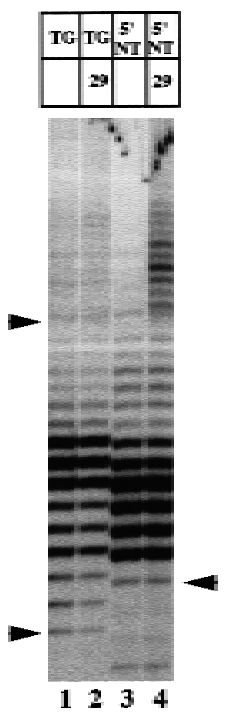

Figure 3. Formation of a stable enzyme-product complex prevents the use of a challenge primer and is not solely dependent on template-substrate base-pairing. (A-E) Products from in vitro tel omerase reactions initiated with one primer (primer $0^{\prime}$, top box), with a second primer added hal fway through the reaction (primer $7^{\prime}$, bottom box). Arrows mark the positions of primer +1 reaction products. Unless indicated otherwise (B), all reactions contained dNTPs throughout the reaction. Primers used are 14 (GTGTGGTGTGTGGG), 29 (GGGTGTGGTGTGTGGGTGTGGTGTGTGGG), 14-478 (GTGTGGTGTGCACG), 14-480 (GTGTGGTGCACGGG), 14* (GTGTGGTGTGTGCA), NT (TAAATTAAACAAACT), and 5' NT (GACCGCGGTGTGTGGG).

added, either together or in separate reactions, at the beginning of the two-stage reactions (lanes 1,2,5). However, neither of these primers was elongated when it was the second, or challenge, primer added after el ongation of the first primer (Fig. 3A, lanes 4,7). The same result was obtained using the primer $(T G)_{7}$, which is efficiently utilized by telomerase (Fig. 3E, lane 1). Although this primer has less complementarity to the template, after being elongated in the first incubation period, it completely blocked use of a second primer (Fig. 3E, lane 2). Failure to el ongate a second, challenge primer was not due to a short half-life of telomerase activity under the reaction conditions, because incubating tel omerase with dNTPs only, omitting primer from the first reaction period still allowed efficient extension of a primer added after that period (Fig. 3A, lanes 3,6). However, strikingly, when tel omerase was incubated for the first reaction period in the presence of primer but without dNTPs, and dN TPs were then added al ong with the challenge primer, there was a large reduction in the subsequent el ongation of both primers (Fig. 3B, lane 3). Additionally, allowing telomerase to add only a single nucleotide to the initiating primer during the first incubation period similarly blocked both extension of the challenge primer and further elongation of the initiating primer (Fig. 3B, lane 2).

Together, these findings demonstrate that tel omerase exists in two distinct states: an active RNP in an elongation-competent state, and a "stall ed" nonel ongatable complex with the telomeric DN A primer or product stably bound to it. The finding that preincubation of telomerase in the presence of primer and the absence of dNTPs is able to prevent elongation of either the initial or the chal lenge primers suggests that primer binding al one is sufficient to induce this stalled state.

The primer challenge assay enabled us to examine the factors contributing to the formation and stability of the nonproductive stalled telomerase-product complex. First, the role of RNA template-DN A product base-pairing was assessed using two telomeric sequence oligonucleotides, each containing six potential base pairs with the template sequence interrupted by three internal mismatches. N either primer was efficiently el ongated by telomerase (Fig. 3C, lanes 1,4); and neither primer, when present in the first incubation period together with telomerase and dNT Ps, prevented use of a second primer added after the first incubation period (Fig. 3C, Ianes 3,6). Furthermore, primer 14*, which al so has a largely telomeric sequence that can potentially form seven uninterrupted base pairs with the TLC 1 templating domain, but cannot be efficiently el ongated by telomerase because it contains two mismatches at its $3^{\prime}$ end, also was unable to bl ock chal lenge primer utilization (Fig. 3D, Ianes 1,2). Likewise, a completely nontelomeric oligonucleotide, which was not a telomerase substrate, did not prevent the use of the telomeric chall enge primer (Fig. 3D, lanes $3,4)$. Hence, incubation of telomerase in the presence of an excess of an oligonucleotide that had mismatches with the template, or was not a substrate for el ongation, did not induce formation of the nonproductive stalled state of telomerase.

The contributions of interactions outside the template region were also assessed, using an initial primer con- 
taining nontelomeric residues at its $5^{\prime}$ end $\left(5^{\prime} \mathrm{NT}\right)$ but with the same nine potential base pairs with the TLC1 RN A template as the standard 14-nucl eotide primer. AIthough primer 5' NT was itself efficiently extended, it also allowed a second, challenge primer to be extended (Fig. 3E, lanes 3,4). Thus, sequences at the $5^{\prime}$ end of the primer, internal to the region predicted to anneal to the RNA template, are required to stabilize the tel omerase/ reaction product complex. This result demonstrates that the stability of the enzyme/product complex is not solely due to Watson-Crick base-pairing between the DNA reaction product and the RNA template domain. Thus, the unusually stable enzyme-product complex we have found in yeast tel omerase involves interactions between the DNA product and the telomerase RN P in addition to the predicted Watson-Crick base-pairing between the product and the template of the TLC 1 RNA.

The stalled telomerase-telomeric DNA complex described here may be the counterpart of the "dead-end" ternary complex formed by Escherichia coli RNA polymerase and its product and template following polymerization on certain template sequences ( $\mathrm{N}$ udler et al. 1995). Release of the stalled RNA polymerase complex involves cleavage of the 3 ' end of the product, a reaction that has also been reported for several telomerases, including S. cerevisiae telomerase (Collins and Greider 1993; Melek et al. 1996; Prescott and Blackburn 1997). However in the case of S. cerevisiae tel omerase, frequent stalling has been proposed to be part of the normal action of the enzyme in vivo, as this mode of synthesis can explain the degenerate telomeric repeat seen in S. cerevisiae telomeres (Singer and Gottschling 1994; Cohn and Blackburn 1995; Prescott and Blackburn 1997) and the lack of processivity demonstrated in vivo (Prescott and Blackburn 1997).

The S. cerevisiae tel omerase complex has at least two active sites

Previously, we described a mutant template tel omerase, 476GUG. In both tlc1-476GU G haploid cells (Prescott and Blackburn 1997) and tlc1-476GUG/tlc1-476GU G diploid cells (A. dePace, J. Prescott, and E.H. Blackburn, unpubl.), tlc1-476GU RNA is found at normal levels in a stable telomerase RN P complex but telomerase is inactive. However, 476GUG telomerase activity was restored, both in vivo and in vitro, by coexpressing wildtype TLC1 RNA gene with the mutant tlc1-476GU G RNA gene (i.e., in TLC1/tlc1-476GUG heterozygous diploids; Prescott and Blackburn 1997). These observations suggested that the restoration of activity to the tlc1-476GUG-containing telomerase requires assembly of this mutant RNA into an active RNP in the presence of wild-type TLC1 RN A. Therefore we tested a possible explanation for this observation that has not been suggested previously, namely that telomerase acts as a multimer (Fig. 4A). Estimates of the macromolecular form of the tel omerase RN P have been confounded by the lack of suitable RN P standards for comparison. The partially purified $S$. cerevisiae telomerase complex characterized here sedimented in a glycerol gradient as a single symmetric peak (Fig. 4B), indicating a single predominant form of the enzyme (i.e., either monomeric or dimeric). The sedimentation coefficient of this telomerase preparation (24S), was comparable to that reported for unfractionated S. cerevisiae telomerase (Lingner et al. 1997).
Figure 4. Telomerase is active as a dimer. (A) Model of dimeric (left) or monomeric (right) telomerase in the presence of 5'-biotinylated (top) and nonbiotinylated (bottom) primers. (B) TLC1 RNA content (arbitrary units) of tel omerase separated on a $25 \%$ (fraction 93 ) to $45 \%$ (fraction 1) glycerol gradient. Arrows indicate positions of thyroglobulin (698 kD), ferritin (418 kD), catal ase (206 kD), and aldolase (167 kD). (C) Products from in vitro telomerase reactions (lanes 1-3) were incubated with streptavidin and separated into unbound (lanes 4-6) and bound (lanes 7-9) fractions. Primers used are 14 (GTGTGGTGTGTGGG) and B42 (GGGTGTGGTGTGTGGGTGTGGTGTGTGGGTGTGGTGTGTGGG, biotinylated at the $5^{\prime}$ end). Arrows indicate primer +1 products.
A

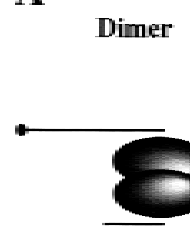

B

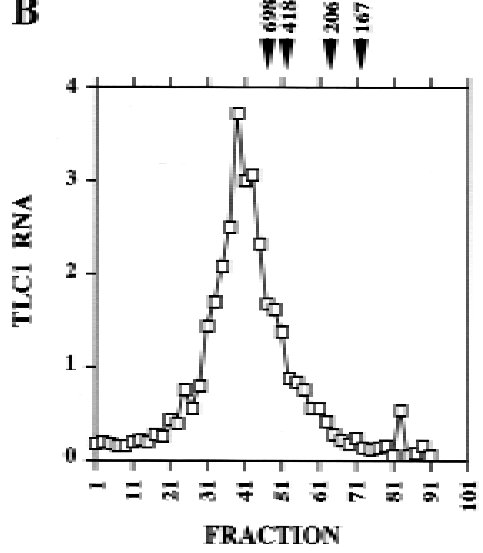

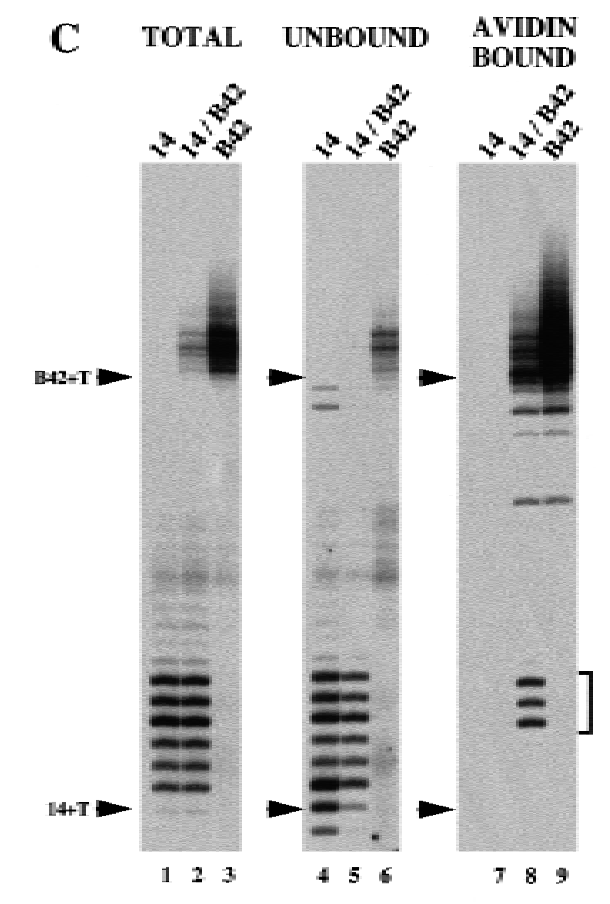


Although the size of telomerase prepared from several species has been estimated using gel filtration chromatography or glycerol gradient sedimentation (Lingner and Cech 1996; Lingner et al. 1997; Nakayama et al. 1997; Wang and Blackburn 1997), these measurements do not distinguish monomeric from dimeric complexes. The nondissociative behavior of S. cerevisiae tel omerase described above, together with the ability to distinguish between utilization of wild-type RNA and 476GUG mutant RNA utilization, all owed us to test directly the possibility that the $S$. cerevisiae telomerase RN P contains more than one active site.

Wild-type telomerase was incubated with two telomeric primers, one biotinylated at its $5^{\prime}$ end and the other unbiotinylated. The sets of products from each primer were distinguishable because of their different lengths. Both primers, together or separately, were elongated by tel omerase in vitro (Fig. 4C, lanes 1-3), although with both primers present in the same reaction, the unbiotinylated primer was used four times more than the biotinylated primer (Fig. 4C, lane 2; see Materials and M ethods). If a single telomerase RN P contains more than one active site (Fig. 4A, dimer), then reaction products of both the biotinylated and the nonbiotinylated primers will copurify on streptavidin. In contrast, if telomerase contains a single active site (Fig. 4A, monomer), then only the biotinylated reaction products will bind to streptavidin. With both primers present in the same elongation reaction, a subset of the nonbiotinylated products copurified with the biotinylated products on streptavidin (Fig. 4C, cf. bracketed bands in lane 8 with Iane 2). Quantitation of the bound ${ }^{32} \mathrm{P}$-labeled products showed that for every biotinylated reaction product bound, no more than one reaction product from the unbiotinylated primer was bound to streptavidin (Fig. 4C, lane 8), despite the fourfold excess of total unbiotinylated reaction products (Fig. 4C, lane 2). This is the result expected if coretention on streptavidin depends on the nondissociative elongation of one biotinylated and one unbiotinylated primer by the same telomerase RN P (Fig. $4 \mathrm{~A}$, dimer). The efficiency of copurification of the nonbiotinylated reaction products on streptavidin was almost exactly that predicted for a polymerase with two active sites (see Materials and M ethods). Furthermore, the preferential coretention of the $+5,+6$, and +7 unbiotinylated reaction products was consistent with the length dependence for the most stable enzyme-product association described above. This preferential coretention of specific telomerase products also demonstrated that coretention was not the result of nonspecific interactions between bi otinylated and nonbiotinylated oligonucleotides but, rather, was limited to oligonucl eotides that had been extended by telomerase. In control reactions containing only one primer substrate, the biotinylated reaction products bound to streptavidin while the unbiotinylated ones did not, as expected (Fig. 4C, cf. lanes 3, 6, and 9, upper bands, and cf. lanes 1, 4, and 7, lower bands). From the specific coretention of unbiotinylated with biotinylated reaction products on streptavidin, we conclude that the active S. cerevisiae telomer- ase RNP complex contains two or more active sites. These combined data are most simply consistent with a homogeneous tel omerase compl ex contai ning two active sites, al though it cannot be ruled out that this complex is trimeric or tetrameric.

The 476GU G mutant telomerase RNA is only active in a telomerase complex containing wild-type telomerase RNA

As described above, the 476GUG telomerase RN A cannot function al one but is functional when coexpressed in the same cell with wild-type tel omerase RNA. We used the same assay described in the previous section to test whether this transactivation of the 476GUG telomerase required that the 476 GUG RNA be present in the same heterodimeric complex with wild-type TLC1 RNA. Telomerase was prepared from TLC 1/tIc1-476GU G diploid cells and incubated with a 40-nucleotide biotinylated primer (B40*) specific for the 476GUG template mutant telomerase, in the presence of either wild-typespecific (14) or mutant-specific $\left(14^{*}\right)$ unbiotinylated primer. If the 476GUG template was utilized by a heterodimeric (wild-type/476GUG) enzyme, then wild-type specific (14) reaction products would copurify with B40* reaction products on streptavidin (Fig. 5, A, top, and B, lanes 4-6). Similarly, if homodi meric 476GU G / 476GUG telomerase was active, then the mutant-specific $\left(14^{*}\right)$ reaction products would also copurify with $\mathrm{B} 40^{*}$ reaction products (Fig. 5, A, bottom, and B, lanes 1-3). The various combinations of biotinylated and unbiotinylated, wild-type-specific and mutant-specific, primers were tested in reactions with telomerase from TLC/tlc1476GU G cells (Fig. 5; data not shown). Strikingly, while the wild-type-specific unbiotinylated reaction products copurified with the mutant-specific biotinylated reaction products, mutant-specific unbiotinylated reaction products did not (Fig. 5B, cf. lanes 3 and 6, bracket). This result demonstrated that while 476GU R R A templates the addition of telomeric DNA in wild-type/476GUG heterodimeric telomerase, 476GUG/476GUG homodimers were nonfunctional. This finding further demonstrated that coretention of biotinylated and unbiotinylated products does not result from nonspecific interactions between DNA reaction products, including DNA-DNA interactions that might have occurred on the enzyme complex. The inactive, homodimeric 476GUG/476GUG telomerase isolated from tlc1476GU G haploids was assembled into an RN P complex that appeared indistinguishable from wild-type telomerase, as assessed by its comigration with wild-type tel omerase in native gel electrophoresis (Fig. 5C). Hence, even by itself the 476GUG tel omerase RNA is capable of assembly into a normally migrating RN P complex, but the complex is enzymatical ly inactive. In summary, we conclude that the mutant 476GUG telomerase RNA template can only be utilized when assembled into an RN P telomerase complex that al so contains wild-type telomerase RNA. 


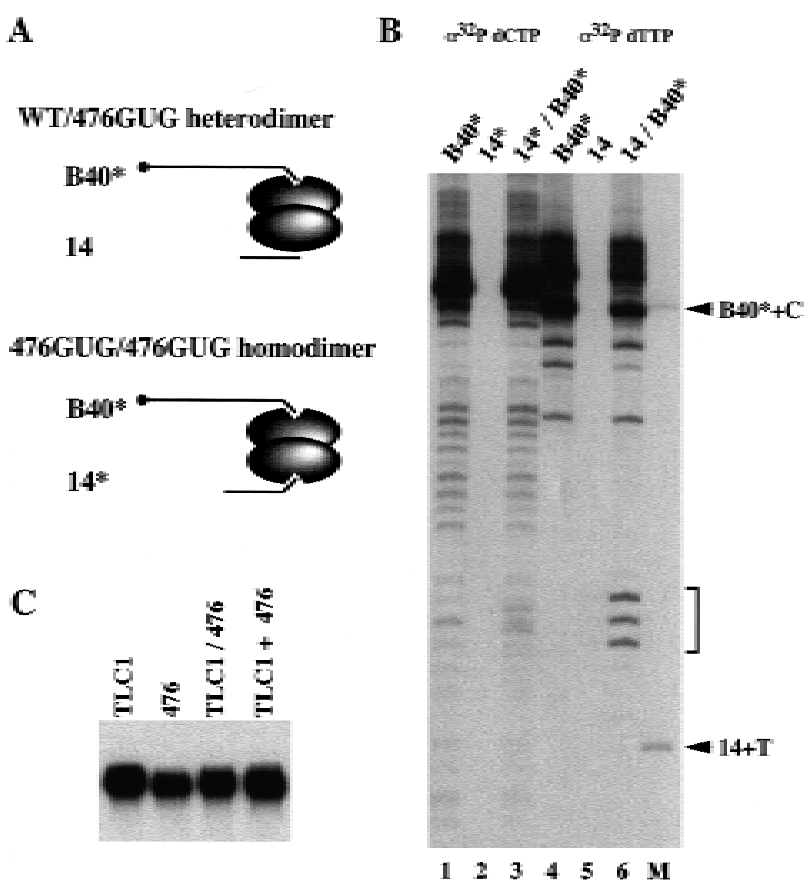

Figure 5. 476GU G tel omerase is only active as a 476GUG/WT heterodimer. (A) Model of 476GUG/WT (wild type) heterodimeric (top) or 476GU G / 476GUG homodimeric (bottom) telomerase in the presence of biotinylated and nonbiotinylated primers. (B) Products from in vitro telomerase reactions were incubated with the indicated primers, bound to streptavidin, washed, and eluted. Primers used are either mutant specific (B40*, GTGTGGTGTGTGGGTGTGGTGTGTGGGTGTGGTGTGTGCA, biotinylated at the 5' end, or 14*, GTGTGGTGTGTGCA), or wild-type-specific (14, GTGTGGTGTGTGGG). Arrows indicate primer +1 products. Control reactions containing only a single primer show that binding to streptavidin is dependent on the presence of biotin (cf. lanes 1 and 4 with biotinylated primers with lanes 2 and 5 with nonbiotinylated primers). (C) Telomerase prepared from TLC1 haploids, tlc1476GU G haploids, or TLC1/tlc1-476GU G diploids was separated, along with a 1:1 mixture of the two haploid enzyme preparations, on a $3 \%$ acrylamide/ $0.6 \%$ agarose native gel, transferred to nytran, and hybridized to a labeled TLC1 DNA probe.

\section{Discussion}

Yeast telomerase and other polymerases

Here we have taken advantage of the finding that S. cerevisiae telomerase forms a stable compl ex with its telomeric DN A product to demonstrate that this tel omerase RNP contains at least two active polymerization sites. Hence, this telomerase is active as a multimeric, most likely dimeric, polymerase (Fig. 6). This is the first such demonstration for any telomerase. We were prompted to test the possibility of a functional higher order structure for tel omerase by our previous genetic results with the 476GUG telomerase RN A mutant of S. cerevisiae: This mutant telomerase RNA was functional in vivo and in vitro only when coexpressed with another, functional telomerase RN A (Prescott and Blackburn 1997). Further- more, restoration of $476 \mathrm{GUG}$ RNA function is al lele specific: Two mutated telomerase RNAs, the template-region mutants 467GUG and 472GUG, are competent to restore 476GUG function, whereas two other telomerase RNA template mutants, 478GUG and 480GUG, fail to do so (J. Prescott, E.H. Blackburn, A. dePace, and S. Chan, unpubl.). These novel findings provide the first evidence for functional interaction and interdependence between two different telomerase RNA molecules in the telomerase RNP.

The action of DNA polymerases in the form of dimers is a commonly recurring theme. A dimeric yeast tel omerase is a possible parallel to dimeric chromosomal replicases, which carry out coordinated leading and lagging strand DN A syntheses at the replication fork. This has been shown directly for the E. coli polymerase III holoenzyme complex (Stukenberg and O'Donnell 1995), which contains two active polymerases tethered to each other by the $\tau$ dimer (Studwell-Vaughan and O'Donnell 1991; Onrust et al. 1995). Despite the disparate functions of its two core pol ymerases, this hol oenzyme is symmetric, with both core polymerases capable of polymerizing

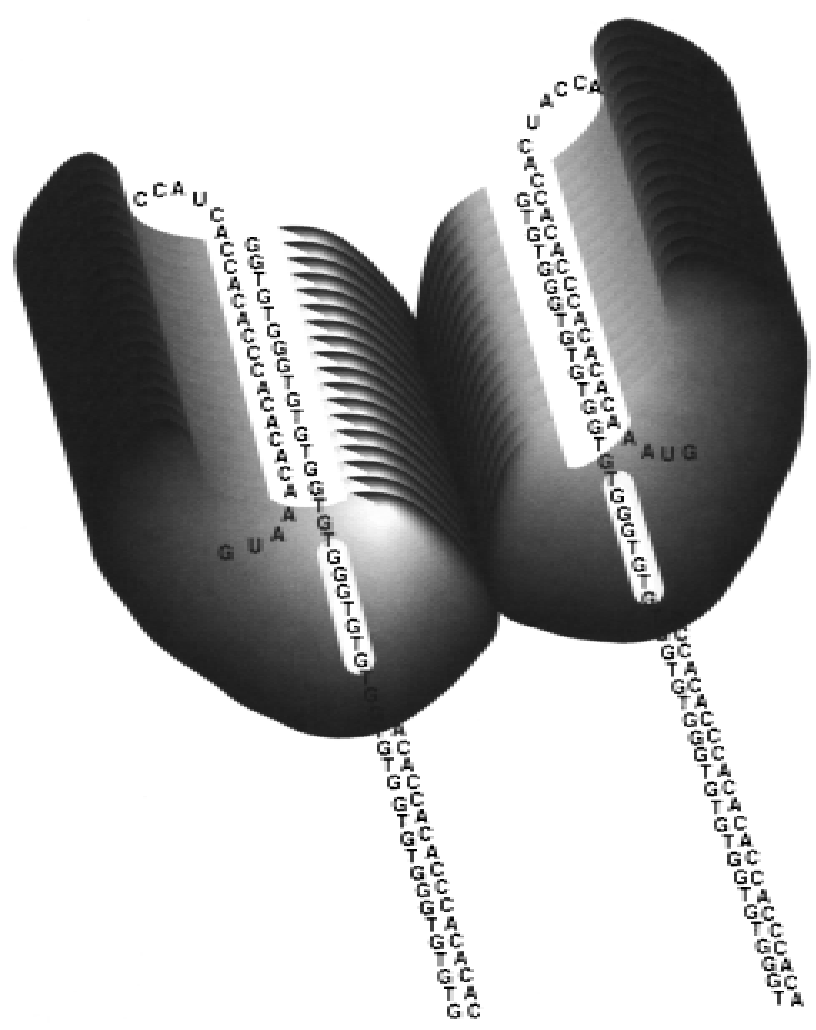

Figure 6. Model of dimeric yeast tel omerase bound to two tel omeric substrates. The two tel omeric substrates have both been partially extended by the two active sites in a single tel omerase RN P. Stable association of the enzyme complex with the telomeric substrates is mediated both by Watson-Crick interactions between the telomeric DNA and template RNA and by interactions between the telomeric DNA and a second primer binding site (open spaces containing primers) in the RNP. The extent of the single-stranded tel omeric $3^{\prime}$ overhang, shown here as $\sim 25$ nucleotides, is not known. 
leading strand synthesis in vitro (Yuzhakov et al. 1997). HIV-1, HIV-2, and Rous sarcoma virus (RSV) contain dimeric reverse transcriptases (RTs) (Hottiger and Hubscher 1996). However, unlike yeast telomerase, only one active site (that in the 66-kD subunit) in the two subunits of HIV-1 RT has polymerase activity (Restle et al. 1992), even though the 51-kD proteolytically derived subunit (Farmerie et al. 1987; M ous et al. 1988) contains all of the RT active site residues.

\section{Specificity and stability of the tel omerase-product complex}

We have demonstrated that the tel omerase RN $P$ remains tightly associated with its telomeric reaction products, in a complex that is stable to gel filtration, native gel electrophoresis, and affinity chromatography. Furthermore, the stability of this complex is determined by additional interactions between the primer and enzyme besides the predicted Watson-Crick base-pairing interactions between the $3^{\prime}$ end of the primer and the template domain of the TLC1 RN A. Purification of this enzymeproduct complex away from free substrate and dNTPs allowed us to specifically cross-link reaction products, which had been ${ }^{32} \mathrm{P}$-labeled by telomerase at the $3^{\prime}$ end (i.e., at the enzyme's active site), to an 103-kD protein subunit of the telomerase RN P. Candidates for this labeled protein are the 103-kD Est2p, a protein containing conserved RT motifs that is required for telomere maintenance in vivo and for telomerase activity in vitro (Lendvay et al . 1996; Lingner et al . 1997), and the 103-kD Cdc13p, which binds singlestranded telomeric DN A in vitro (Nugent et al. 1996). However, in these experiments any Cdc13p that may have been present would have been competed for by the vast excess of unlabeled telomeric DNA primer oligonucleotide. Hence, the 103-kD cross-linked protein is likely to be Est2p, consistent with Est $2 p$ being the catalytic protein subunit of S. cerevisiae tel omerase.

A nondissociative dimeric telomerase can account for previous in vivo results with template mutants

The data reported here suggest that rather than dissociating prematurely from the telomere, as has been proposed previously (Singer and Gottschling 1994; Cohn and Blackburn 1995), the el ongating S. cerevisiae telomerase has a high probability of relaxing into an unproductive, stalled conformation containing bound telomeric DNA. This can occur after binding a telomeric substrate and also after each polymerization step along the template. Our data suggest that the association between telomeric DN A and the telomerase RN P is stabilized by interactions of the newly synthesized tel omeric DN A with both the RN A template and some other component of telomerase. These findings raise the possibility that telomerase may be "clamped" to the telomere during at least some fraction of the cell cycle, perhaps helping to cap the newly synthesized $3^{\prime}$ overhang. This model can account for two hitherto poorly understood observations on telomeres in vivo.
First, telomeric DNA synthesized in vivo in the presence of both a wild-type and a template mutant telomerase contains a highly nonrandom distribution of wildtype and mutant repeats: nearly all of the mutant repeats were cl ustered into tracts of closely interspersed mutant and wild-type repeats. Such clustering is consi stent with synthesis by a dimeric telomerase in which the second template has a high probability of being the next one copied. This finding implies that the telomerase complex spends sufficient time at the telomere at which it has recently acted to increase the probability that the same complex is used for the next elongation event. The telomeric DN A synthesized in vivo in this situation has patterns consistent with all the properties of the telomerase reaction we have observed in vitro (Prescott and Blackburn 1997). Most of the newly added telomeric DNA consisted of uninterrupted tracts of wild-type repeats, consistent with the in vitro observation that the mutant telomerases are less active than the wild-type enzyme (Prescott and Blackburn 1997). Telomere addition by wild-type homodimers, which are likely to be the most active form of the enzyme, would generate the purely wild-type telomeric tracts, whereas addition by mutant/wild-type heterodimers would give rise to the interspersed wild-type and mutant repeats. The lack of long stretches of uninterrupted mutant repeats are consistent with both the inherently low processivity of yeast telomerase and the observed decreased activity of the mutant homodimers.

A second unexpected in vivo result is that senescence in tIc1-476GU G cells began when tel omeres were 100 bp longer than the short, but stable, telomeres seen in other template mutant strains analyzed that showed no signs of senescence (Prescott and Blackburn 1997). This observation suggests that the early onset of senescence of the tlc1-476GU G cells is not due solely to telomere shortening below some critical length. We propose that in tlc1-476GU G cells, the lack of a telomerase RNP that would normally be present on the telomere following polymerization could contribute to the early senescence. Proteins that specifically bind the tel omeric $3^{\prime}$ overhang and could act in the capping of the telomere have been characterized in the ciliated protozoa Euplotes crassus and Oxytricha nova (Gottschling and Zakian 1986; Price and Cech 1987; Price 1990). Although proteins have been identified in Xenopus (Cardenas et al. 1993), Chlamydomonas (Petracek et al. 1994), and S. cerevisiae (Lin and Zakian 1994; Konkel et al. 1995) based on their ability to bind telomeric G-strand single-stranded DNA (ssDNA) in vitro, their roles and presence at telomeres are unknown, and these $S$. cerevisiae proteins are not essential for telomere maintenance. Two additional S cerevisiae proteins that are required for normal telomere maintenance in vivo, Cdc13p and Estlp, bind telomeric Gstrand ssDN A in vitro (N ugent et al. 1996; Virta-Pearlman et al. 1996), although their presence at telomeres has not been tested. The novel properties we described here for S. cerevisiae telomerase suggest that this RN P polymerase might itself be a structural component of a telomere cap, helping to protect the newly synthesized 
$3^{\prime}$ overhang from recombination and degradation activities. Telomerase may remain stably bound to the telomere throughout all or part of the cell cycle, may be displaced by a replication fork or helicase during DN A replication, or may be replaced at some point in the cell cycle by putative end-binding proteins such as Cdc13p and Estlp.

Possible roles for higher-order tel omerase interactions in telomere-tel omere association

Associations between telomeres have been observed in both meiotic and mitotic cells of many eukaryotes (Chikashige et al. 1994; Dernberg et al. 1995; Gotta et al. 1996; Scherthan et al. 1996; Kirk et al. 1997). The demonstration here that a single yeast telomerase enzyme complex can remain stably associated with two different telomeric oligonucleotide reaction products opens the possibility that the telomerase RNP is involved in mediating telomere-telomere associations in vivo (Fig. 6). In S. cerevisiae, telomeres cluster in the nucleus, and although they colocalize with Rap1p, Sir3p, and Sir4p (Gotta et al. 1996), deletion of either SIR3 or SIR4 does not prevent telomere clustering (Pall adino et al . 1993). It was recently demonstrated that expressing a template mutant tel omerase in Tetrahymena cells caused a block in late anaphase, with newly replicated chromosomes becoming stretched to up to twice their normal length and failing to separate, suggesting aberrant telomeretelomere associations (Kirk et al. 1997). A telomerase containing two or more active sites, each of which remains stably bound to its newly elongated product at the telomeric terminus, is one candidate for the "glue" that initiates, facilitates, or even mediates normal or abnormal telomere-telomere associations. It will be interesting to see how telomere association is affected in cells lacking functionally interacting telomerase RNAs.

\section{Materials and methods}

Extract preparation, fractionation, and in vitro telomerase reactions

Whole-cell extracts were prepared, fractionated on DEAE-agarose, and concentrated 8- to 10-fold, as described previously (Prescott and Blackburn 1997). Unless indicated otherwise, re actions containing 50\% (vol/vol) DEAE fraction, $50 \mathrm{~mm}$ Tris$\mathrm{HCl}\left(\mathrm{pH}\right.$ 8), $1 \mathrm{~mm}$ spermidine, $1 \mathrm{~mm}$ DTT, $7.5 \mu \mathrm{m}\left[\alpha_{-}{ }^{32} \mathrm{P}\right] \mathrm{dTT} \mathrm{P}$ (400 Ci/mmole), $10 \mu \mathrm{m}$ each unlabeled dNTP, and $1 \mu \mathrm{m}$ primer were incubated at $30^{\circ} \mathrm{C}$ for $30 \mathrm{~min}$, and analyzed as described previously (Prescott and Blackburn 1997). In the time course reaction, all reaction components were prewarmed to $30^{\circ} \mathrm{C}$ before being mixed together, and al iquots were stopped with onetenth volume of stop buffer (2\% SDS; $250 \mathrm{~mm}$ EDTA; $250 \mathrm{~mm}$ Tris- $\mathrm{HCl}$ at $\mathrm{pH}$ 7.7) at the indicated times. Primer challenge reactions were incubated for $7 \mathrm{~min}$ with the initiating primer followed by another $7 \mathrm{~min}$ with the challenge primer. Reaction products were quantified using a M ol ecular Dynamics Phosphorlmager. Product yield represents the sum of the +1 through +7 reaction products, taking into account the different specific activities of the variously el ongated reaction products, and is expressed in arbitrary units.
Sephacryl S-300 filtration chromatography, native gel el ectrophoresis, and Northern analysis

Seventy-five-microliter reactions were incubated at $30^{\circ} \mathrm{C}$ for 7 min, loaded onto a 2-ml Sephacryl S-300 column (Pharmacia), and eluted in TMG. Half of each $60-\mu \mathrm{l}$ fraction was Cerenkov counted and then separated on a $15 \%$ denaturing acrylamide gel. In addition to the +1 to +7 telomerase reaction products shown, reactions contained high-molecular-weight, RN ase-insensitive, primer-independent, nontelomerase reaction products (data not shown). The other half was loaded onto a $3 \%$ acrylamide (80:1 acrylamide/bis-acrylamide)/0.6\% agarose nondenaturing gel and electrophoresed in $50 \mathrm{~mm}$ Tris-acetate at $200 \mathrm{~V}$. Followeing a 48-hr exposure to film, the gel was incubated in $50 \%$ urea for 2 min and transferred to Hybond Plus nytran membrane (Amersham) in 0.5 XTBE. The membrane was first exposed to film for $2 \mathrm{hr}$ and then hybridized to a ${ }^{32} \mathrm{P}$-label ed 1.3-kb DN A fragment containing the TLC1 gene, according to Church and Gilbert and re-exposed to film for $2 \mathrm{hr}$. The heterogeneously sized reaction products are assumed to be the nontelomerase-generated reaction products mentioned above and described previously (Cohn and Blackburn 1995; Prescott and Blackburn 1997).

\section{UV cross-linking}

In vitro tel omerase reactions containing $1 \mu \mathrm{M}$ GGTGTGGTGTGUGGG and $1 \mu \mathrm{m}$ GGUGTGGTGTGTGGG (U is $\left.5^{\prime} \mathrm{IdU}\right)$ were separated on Sephacryl S-300 as described above. Fifty-microliter fractions were collected in a 96-well plate and exposed to 254 nm UV light (Stratagene Stratalinker) for $5 \mathrm{~min}$ on ice. Void volume fractions eluting prior to free oligonucleotides and $\left[{ }^{32} \mathrm{P}\right] \mathrm{dN}$ TPs were pooled, digested with $20 \mu \mathrm{g} / \mathrm{ml}$ of RNase A and 0.005 units of DNase I (Promega), precipitated with $10 \%$ TCA and $6 \%$ acetone, separated on a $9 \%$ acryladmide SDS gel, and exposed to film.

\section{Glycerol gradient sedimentation}

Seventy-five microliter telomerase containing DEAE fraction (Prescott and Blackburn 1997) was loaded onto a 12-ml 25\%$45 \%$ glycerol gradient containing $0.1 \%$ Triton X-100 in the presence of $3 \mathrm{mg} / \mathrm{ml}$ each of thyroglobulin, ferritin, catalase, and aldolase and centrifuged at 40,000 rpm for $24 \mathrm{hr}$ in an SW41 rotor at $4^{\circ} \mathrm{C}$. Fractions of $130 \mu \mathrm{l}$ were collected and TLC1 RN A quantitated by dot blot hybridization with a TLC1 gene probe. Protein size standards were visualized by SDS-PAGE followed by staining with Coomassie brilliant blue.

\section{Streptavidin affinity chromatography}

Immobilized NeutrAvidin Plus (Pierce) was preblocked for 30 min at $4^{\circ} \mathrm{C}$ in TMG containing $0.75 \mathrm{mg} / \mathrm{ml}$ each of BSA, lysozyme, casein, and cytochrome $c$ and $0.15 \mathrm{mg} / \mathrm{ml}$ each of glycogen, tRN A, and yeast RN A, washed twice (15 minutes each) at $4^{\circ} \mathrm{C}$ in TM G and resuspended in TM containing $0.2 \mathrm{mg} / \mathrm{ml}$ of tRNA, $0.1 \mathrm{mg} / \mathrm{ml}$ each of nonspecific oligonucleotides (AACCCGACTATGCTATTTTAATC and GTACACCACATACCTAATCAAATCCCTATAGTCAGTCGTATTA), $0.2 \mathrm{mg} / \mathrm{ml}$ of casein, and $1 \%$ Triton $X-100$. Telomerase reactions were incubated at $30^{\circ} \mathrm{C}$ for $5 \mathrm{~min}$. Preblocked Immobilized N eutrA vidin Plus (15 $\mu \mathrm{l} / 50-\mu \mathrm{l}$ DEAE fraction) was then added and reactions were continued for $10 \mathrm{~min}$ at $30^{\circ} \mathrm{C}$ followed by $15 \mathrm{~min}$ on ice. The resin was washed three times at $4^{\circ} \mathrm{C}$ in TMG containing 0.1 $\mathrm{mg} / \mathrm{ml}$ of casein, $0.5 \%$ Triton $\mathrm{X}-100$, and $0.4 \mathrm{M} \mathrm{N} \mathrm{aOAC}$, once in the same buffer containing $0.6 \mathrm{M} \mathrm{NaOAC}$ at $30^{\circ} \mathrm{C}$, and twice at room temperature in the same buffer containing $0.4 \mathrm{M} \mathrm{N}$ aOAC. Bound reaction products were eluted by incubation at $65^{\circ} \mathrm{C}$ 
with $0.2 \%$ SDS followed by phenol extraction. Total and unbound fractions each represent $10 \%$ of the total reaction, avidinbound fractions represent the remaining $80 \%$.

\section{Quantitation of streptavidin copurification}

Reaction prdoucts ( +1 through +7 bands) were quantitated from two independent experiments on a Phosphorlmager. The unbiotinylated 14-474 primer was extended 4.2 times more efficiently than the biotinylated B-42-474 primer when both were present in the same reaction (i.e., $81 \%$ unbiotinylated and $19 \%$ biotinylated reaction products). From this, we calculate that $66 \%$ $(81 \% \times 81 \%)$ of the dimeric polymerases will contain two unbi otinylated reaction products and therefore are not expected to bind to streptavidin; $4 \%(19 \% \times 19 \%)$ will contain two biotinylated reaction products; and $31 \%[2(81 \% \times 19 \%)]$ will contain one of each, and these complexes can both bind streptavidin. Hence, for a telomerase with two active sites, $39(31+4+4)$ biotinylated reaction products are expected to bind streptavidin for every 31 unbiotinylated reaction product, giving a predicted ratio of 1.25:1 biotinylated to unbi otinylated reaction products. Our observed ratio of 2.7:1 can be explained by the fact that only the $+5,+6$, and +7 reaction products, which account for $50 \%$ of the 14-474-derived reaction products, remain bound through the extensive washes of the streptavidin resin.

\section{Acknowledgments}

We thank Jagoree Roy, Sandy Johnson, and Tom Cech for critical reading of this manuscript, and members of the Blackburn laboratory for hel pful discussions. This work was supported by grants GM 26259 and DE11356 from the N ational Institutes of Health (to E.H.B.). J.P. was supported by a postdoctoral fellowship from the Damon Runyan-Walter Winchell Cancer Fund.

The publication costs of this article were defrayed in part by payment of page charges. This article must therefore be hereby marked "advertisement" in accordance with 18 USC section 1734 solely to indicate this fact.

\section{References}

Blackburn, E.H. 1994. Telomeres: N o end in sight. Cell 77: 621623.

Blasco, M.A., W. Funk, B. Villeponteau, and C.W. Greider. 1995. Functional characterization and developmental regulation of mouse telomerase RN A. Science 269: 1267-1270.

Cardenas, M.E., A. Bianchi, and T. de Lange. 1993. A Xenopus egg factor with DNA-binding properties characteristic of terminus-specific telomeric proteins. Genes \& Dev. 7: 883894.

Chikashige, Y., D.Q. Ding, H. Funabiki, T. Haraguchi, S. Mashiko, M. Yanagida, and Y. Hiraoka. 1994. Telomereled premeiotic chromosome movement in fission yeast. Science 264: 270-273.

Chong, L., B. van Steensel, D. Broccoli, H. Erdjument-Bromage, J. Hanish, P. Tempst, and T. de Lange. 1995. A human telomeric protein. Science 270: 1663-1667.

Cohn, M. and E.H. Blackburn. 1995. Telomerase in yeast. Science 269: 396-400.

Collins, K. and C.W. Greider. 1993. Tetrahymena telomerase catalyzes nucleolytic cleavage and nonprocessive elongation. Genes \& Dev. 7: 1364-1376.

Collins, K., R. Kobayashi, and C.W. Greider. 1995. Purification of Tetrahymena telomerase and cloning of genes encoding the two protein components of the enzyme. Cell 81: 677686.
Dernberg, A.F., J.W. Sedat, W.Z. Cande, and H.W. Bass. 1995. Cytology of tel omeres. In Telomeres (ed. E. Blackburn and C. Greider), pp. 96-105. Cold Spring Harbor Laboratory Press, Cold Spring Harbor, NY.

Farmerie, W.G., D.D. Leob, N.C. Casavant, and C.A.D. Hutchinson. 1987. Expression and processing of the AIDS virus reverse transcriptase in Escherichia coli. Science 236: 305308.

Feng, J., W.D. Funk, S.S. Wang, S.L. Weinrich, A.A. A vilion, C.P. Chiu, R.R. Adams, E. Chang, R.C. Allsopp, J. Yu et al. 1995. The RNA component of human telomerase. Science 269: 1236-1241.

Fitzgerald, M.S., T.D. M cKnight, and D.E. Shippen. 1996. Characterization and developmental patterns of telomerase expression in plants. Proc. Natl. Acad. Sci. 93: 14422-14427.

Gotta, M., T. Laroche, A. Formention, L. M aillet, H. Scherthan, and S. Gasser. 1996. The clustering of telomeres and colocalization with Rap1, Sir3, and Sir4 proteins in wild-type Saccharomyces cereviaie. J. Cell Biol. 134: 1349-1363.

Gottschling, D.E. and V.A. Zakian. 1986. Telomere proteins: specific recognition and protection of the natural termini of Oxytricha macronuclear DNA. Cell 47: 195-205.

Greider, C.W. 1996. Telomere length regulation. Annu. Rev. Biochem. 65: 337-365.

Greider, C.W. and E.H. Blackburn. 1985. Identification of a specific tel omere terminal transferase activity in Tetrahymena extracts. Cell 43: 405-413.

-_- 1989. A tel omeric sequence in the RN A of Tetrahymena telomerase required for telomere repeat synthesis. Nature 337: 331-337.

Harrington, L., T. McPhail, V. Mar, W. Zhou, R. Oulton, A.E. Program, M.B. Bass, I. Arruda, and M. Robinson. 1997. A mammalian telomerase-associated protein. Science 275: 973-977.

Henderson, E. 1995. Telomere DNA structure. In Telomeres (ed. E. Blackburn and C. Greider), pp. 11-34. Cold Spring Harbor Laboratory Press, Cold Spring Harbor, NY.

Hottiger, M. and U. Hubscher. 1996. Human immunodeficiency virus type 1 reverse transcriptase. Biol. Chem. Hoppe-Seyler 337: 97-120.

Kirk, K.E., B.P. Harmon, I.K. Reichardt, J.W. Sedat, and E.H. Blackburn. 1997. Block in anaphase chromosome separation caused by a telomerase template mutation. Science 275: 1478-1481.

Klobutcher, L.A., M.T. Swanton, P. Donini, and D.M. Prescott. 1981. All gene sized molecules in four species of hypotrichs have the same terminal sequence and an unusual 3' terminus. Proc. Natl. Acad. Sci. 78: 3015-3019.

Konkel, L.M., S. Enomoto, E.M. Chamberlain, P. M cCune-Zierath, S.J. Iyadurai, and J. Berman. 1995. A class of singlestranded telomeric DNA-binding proteins required for Raplp localization in yeast nuclei. Proc. Natl. Acad. Sci. 92: 5558-5562.

Krauskopf, A. and E.H. Blackburn. 1996. Control of telomere growth by interactions of RAP1 with the most distal telomeric repeats. Nature 383: 354-357.

Lendvay, T.S., D.K. M orris, J. Sah, B. Bal asubramanian, and V. Lundblad. 1996. Sequence mutants of Saccharomyces cerevisiae with a defect in telomere replication identify three additional EST genes. Genetics 144: 1399-1412.

Li, B. and A.J. Lustig. 1996. A novel mechanism for telomere size control in Saccharomyces cerevisiae. Genes \& Dev. 10: 1310-1326.

Lin, J.J. and V.A. Zakian. 1994. Isolation and characterization of two Saccharomyces cerevisiae genes that encode proteins that bind to (TG1-3)n single strand telomeric DN A in vitro. 
Nucleic Acids Res. 22: 4906-4913.

Lingner, J. and T.R. Cech. 1996. Purification of telomerase from Euplotes aediculatus: Requirement of a primer 3 ' overhang. Proc. Natl. Acad. Sci. 93: 10712-10717.

Lingner, J., T.R. Hughes, A. Shevchenko, M. Mann, V. Lundblad, and T.R. Cech. 1997. Reverse transcriptase motifs in the catalytic subunit of telomerase. Science 276: 561-567.

Lundblad, V. and J.W. Szostak. 1989. A mutant with a defect in telomere elongation leads to senescence in yeast. Cell 57: 633-643.

Makarov, V.L., Y. Hirose, and J.P. Langmore. 1997. Long G tails at both ends of human chromosomes suggest a $C$ strand degradation mechanism for telomere shortening. Cell 88: 647-655.

McEachern, M.J. and E.H. Blackburn. 1995. Runaway telomere el ongation caused by telomerase RN A gene mutations. $\mathrm{Na}$ ture 376: 403-409.

M el ek, M.E., E.C. Greene, and D.E. Shippen. 1996. Processing of nontelomeric $3^{\prime}$ ends by tel omerase: default template alignment and endonucleolytic cleavage. Mol. Cell. Biol. 16: 3437-3445.

Meyerson, M., C.M. Counter, E.N. Eaton, L.W. Ellisen, P. Steiner, S.D. Caddle, L. Ziaugra, R.L. Beijersbergen, M.J. Davidoff, Q. Liu, S. Bacchetti, D.A. Haber, and R.A. Weinberg. 1997. hEST 2, the putative human tel omerase catalytic subunit gene, is up-regulated in tumor cells and during immortalization. Cell 90: 785-795.

Morin, G.B. 1989. The human telomere terminal transferase enzyme is a ribonucleoprotein that synthesizes TTAGGG repeat. Cell 59: 521-529.

Mous, J., E.P. Heimer, and S.F.J. LeGrice. 1988. Processing protease and reverse transcriptase from human imunodeficiency virus type 1 polyprotein in Escherichia coli. J. Virol. 62: 1433-1436.

Nakamura, T.M., G.B. Morin, K.B. Chapman, S.L. Weinrich, W.H. Andrews, J. Lingner, C.B. Harley, and T.R. Cech. 1997. Telomerase catalytic subunit homologs from fission yeast and human. Science 277: 955-959.

Nakayama, J.-I., M. Saito, H. Nakamura, A. Matsuura, and F. Ishikawa. 1997. TLP1: A gene encoding a protein component of mammalian telomerase is a novel member of WD repeats family. Cell 88: 875-884.

Nudler, E., M. Kashlev, V. Nikiforov, and A. Goldfarb. 1995. Coupling between transcriptional termination and RNA polymerase inchworming. Cell 81: 351-357.

Nugent, C.I., T.R. Hughes, N.F. Leu, and V. Lundblad. 1996. Cdc13p: A single strand telomeric DNA-binding protein with a dual role in yeast telomere maintenance. Science 274: 249-252.

Olovnikov, A.M . 1973. A theory of marginotomy. J. Theor. Biol. 41: 181-190.

Onrust, R., J. Finkelstein, J. Turner, V. Naktinis, and M. O'Donnell. 1995. Assembly of a chromosomal replication machine: Two DN A polymerases, a clamp loader, and sliding clamps in one hol oenzyme particle. III. Interface between two polymerases and the clamp Ioader. J. Biol.Chem. 270: 13366-13377.

Palladino, F., T. Laroche, E. Gilson, A. Axelrod, L.Pillus, and S.M. Gasser. 1993. SIR3 and SIR4 proteins are required for the positioning and integrity of yeast telomeres. Cell 75: 543-555.

Petracek, M.E. L.M. Konkel, M.L. Kable, and J. Berman. 1994. A Chlamydomonas protein that binds single-stranded $G$ strand telomere DNA. EMBO J. 13: 3648-3658.

Prescott, J. and E.H. Blackburn. 1997. Telomerase RN A mutations in Saccharomyces cerevisiae alter telomerase action and reveal non processivity in vivo and in vitro. Genes \& Dev. 11: 528-540.

Price, C.M. 1990. Telomere structure in Euplotes crassus: Characterization of DNA-protein interactions and isolation of a telomere-binding proteins. Mol. Cell. Biol. 10: 3421-3431.

Price, C.M. and T.R. Cech. 1987. Telomeric DN A-protein interactions of Oxytricha macronuclear DNA. Genes \& Dev. 1: 783-793.

Promisel Cooper, J., E.R. Nimmo, R.C. Allshire, and T.R. Cech. 1997. Regulation of telomere length and function by a M ybdomain protein in fission yeast. Nature 385: 744-747.

Prowse, K.R., A.A. Avilion, and C.W. Greider. 1993. Identification of a nonprocessive telomerase activity from mouse cells. Proc. Natl. Acad. Sci. 90: 1493-1497.

Restle, T., B. Muller, and R.S. Goody. 1992. RN ase H activity of HIV reverse transcriptase is confined exclusively to the dimeric forms. FEBS Lett. 300: 97-100.

Sandell, L.L. and V.A. Zakian. 1993. Loss of a yeast telomere: Arrest, recovery, and chromosome loss. Cell 75: 729-739.

Scherthan, H., S. Weich, H. Schwengler, C. Heyting, M. Harle, and T. Cremer. 1996. Centromere and telomere movements during early meiotic prophase of mouse and man are associated with the onset of chromosome pairing. J. Cell Biol. 134: 1109-1125.

Shippen-Lentz, D. and E.H. Blackburn. 1989. Telomere terminal transferase activity from Euplotes crassus adds large numbers of TTTTGGGG repeats onto telomeric primers. Mol. Cell. Biol. 9: 2761-2764.

Shore, D. 1994. RAP1: A protean regulator in yeast. Trends Genet. 10: 408-412.

Singer, M.S. and D.E. Gottschling. 1994. TLC1: Template RN A component of Saccharomyces cerevisiae telomerase. Science 266: 404-409.

Studwell-Vaughan, P.S. and M. O'Donnell. 1991. Constitution of the twin polymerase of DNA polymerase III holoenzyme. J. Biol.Chem. 266: 19833-19841.

Stukenberg, P.T. and M. O'Donnell. 1995. Assembly of a chromosomal replication machine: Two DNA polymerases, a clamp loader, and sliding clamps in one holoenzyme particle. V. Four different polymerase-clamp complexes on DN A. J. Biol. Chem. 270: 13384-13391.

van Steensel, B. and T. de Lange. 1997. Control of telomere length by the human telomeric protein. TRF1. Nature 385: 740-743.

Virta-Pearlman, V., D.K. M orris, and V. Lundblad. 1996. Est1 has the properties of a single-stranded tel omere end-binding protein. Genes \&Dev. 10: 3094-3104.

Wang, H. and E.H. Blackburn. 1997. De novo telomere addition by Tetrahymena telomerase in vitro. EMBO J. 16: 866-879.

Watson, J.D. 1972. Origin of concatomeric T7 DNA. Nature New Biol. 239: 197-201.

Wellinger, R.J., A.J. Wolf, and V.A. Zakian. 1993. Saccharomyces telomeres acquire single-strand TG1-3 tails late in $\mathrm{S}$ phase. Cell 72: 51-60.

Yu, G.L. and E.H. Blackburn. 1991. Developmentally programmed healing of chromosomes by telomerase in Tetrahymena. Cell 67: 823-832.

Yuzhakov, A., J. Turner, and M. O'Donnell. 1997. Replisome assembly reveals the basis for asymmetric function in leading and lagging strand replication. Cell 86: 877-886.

Zahler, A.M. and D.M. Prescott. 1988. Telomere terminal transferase activity in the hypotrichous ciliate Oxytricha nova and a model for replication of the ends of linear DNA molecules. Nucleic Acids Res. 16: 6953-6972.

Zakian. V.A. 1995. Tel omeres: Beginning to understand the end. Science 270: 1601-1607. 


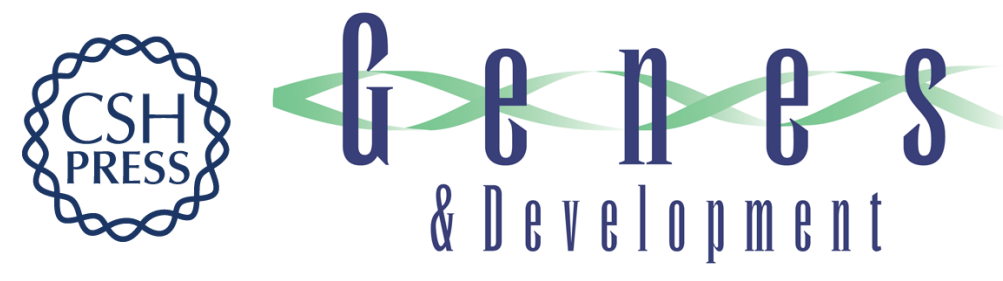

\section{Functionally interacting telomerase RNAs in the yeast telomerase complex}

John Prescott and Elizabeth H. Blackburn

Genes Dev. 1997, 11:

Access the most recent version at doi:10.1101/gad.11.21.2790

References

This article cites 63 articles, 35 of which can be accessed free at: http://genesdev.cshlp.org/content/11/21/2790.full.html\#ref-list-1

\section{License}

Email Alerting

Receive free email alerts when new articles cite this article - sign up in the box at the top Service right corner of the article or click here.

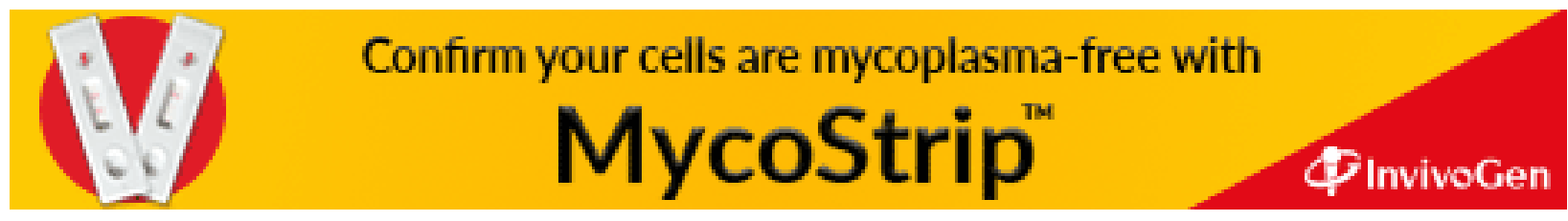

